https://doi.org/10.21516/2072-0076-2021-14-2-63-68

\title{
Dry eye disease and associated factors in Kazakhstan and Uzbekistan
}

Quresh B. Maskati ${ }^{凶}$, Shalini Kumar², Vijaykumar Chaubey², Neelesh Katakwar², Siddhesh Sharma²

${ }^{1}$ Maskati Eye Clinic, Maharshi Karve Road, Charni Road East, Opera House, Girgaon, Mumbai, 400004, India

${ }^{2}$ Ajanta Pharma Limited, Unit No. 301/302, Satellite Gazebo, B Wing, Andheri Ghatkopar Link Road, Chakala, Andheri East, Mumbai, 400093, India

rachita@spellbound.co.in

Dry eye disease (DED) is an ocular condition with a high prevalence globally. The survey was conducted to understand factors that influence the treatment of DED in Kazakhstan and Uzbekistan and the properties of artificial tears required in its treatment. Purpose. The survey aimed to understand the prevalence of DED in the population of Kazakhstan and Uzbekistan, whether associated ocular diseases and patient lifestyle affected DED treatment, the properties of artificial tears required in the treatment of DED, and the use of artificial tears in conditions other than DED. Material and methods. A total of 457 ophthalmologists participated in the survey that was conducted between June-July 2019 in selected cities of Kazakhstan and Uzbekistan. The questionnaire assessed the number of patients with DEs, associated ocular diseases, contributing factors to poor adherence to DED treatment, major concerns in DED and properties of artificial tears required in the treatment of DED. Results. About $73 \%$ of the doctors in Kazakhstan and all the doctors in Uzbekistan reported that DE-associated ocular diseases and lifestyle of a patient contribute to poor adherence to DED therapy. Doctors in Kazakhstan and Uzbekistan ranked hydration at 1.613 and 1.928 , respectively, while considering the properties of artificial tears required for the treatment of DED. Conclusion. A majority of the doctors in Kazakhstan and Uzbekistan considered DE-associated ocular diseases and patient lifestyle as major contributing factors to poor adherence to DED treatment. Doctors from both countries considered hydrating property of artificial tears to be the most important ones for the management of $D E$.

Keywords: glaucoma; dry eye disease; artificial tears; dry eye syndrome

Conflict of interests: There is no conflict of interest.

Financial disclosure: Ajanta Pharma Ltd. Supported the survey conducted, and its analysis.

For citation: Maskati Q.B., Kumar Sh., Chaubey V., Katakwar N., Sharma S. Dry eye disease and associated factors in Kazakhstan and Uzbekistan. Russian ophthalmological journal. 2021; 14 (2): 63-8 (In Russian). https://doi.org/10.21516/2072-0076-2021-14$2-63-68$

\section{Синдром сухого глаза и связанные с ним факторы в Казахстане и Узбекистане}

\author{
К.Б. Маскати ${ }^{1}$, Ш. Кумар², В. Чоби², Н. Катаквар², С. Шарма² \\ ${ }^{1}$ Глазная клиника Маскати, Махарши Карве Роуд, Чарни Ист Роуд, Здание Оперы, Жиргаон, Мумбаи, 400004, Индия \\ ${ }^{2}$ Аджанта Фарма Лтд, блок 301/302, Сателлайт Газибо, Винг Б, Андери Гаткопар Линк Роуд, Чакала, Восточное Андери, \\ Мумбаи, 400093, Индия
}

Синдром сухого глаза (ССГ) - заболевание глаз, широко распространенное в мире. Для лучшего понимания факторов, влияющих на лечение ССГ, а также для определения необходимых для его лечения свойств искусственной слезы, в Казахстане и Узбекистане был проведен опрос среди офтальмологов. Целью этого опроса была оценка распространенности ССГ среди населения Казахстана и Узбекистана, влияния сопутствующих глазных болезней, образа жсизни пациента и свойств искусственной слезы на результатылечения ССГ, а также возможности использования препаратов искусственной слезы при других офтальмопатологиях. Материал и методы. Всего в опросе, который проводился с июня по июль 2019 г. в некоторых городах Казахстана и Узбекистана, приняли участие 457 офтальмологов. В анкете оценивалось количество пациентов с ССГ и ассоциированными с ним глазными заболеваниями, факторы, способствующие приверженности клечению ССГ, основные проблемы, 
связанные с ССГ, а также свойства искусственной слезы, необходимой для лечения этой патологии. Результаты. Около 73 \% врачей, опрошенных в Казахстане, и все врачи, участвовавшие в опросе в Узбекистане, считают, что глазные заболевания, ассоциированные с ССГ, и образ жизни пациента способствуют недооценке со стороны пациентов необходимости терапии этой патологии. Врачи в Казахстане и Узбекистане оценили увлажняюшую способность искусственной слезы, необходимой для лечения ССГ, на уровне 1,613 и 1,928 соответственно. Заключение. Большинство врачей в Казахстане и Узбекистане считают ассоциированные с ССГ глазные заболевания и образ жизни пациентов основными факторами, способствующими плохой приверженности клечению. Врачи из обеих стран считают увлажняюшую способность искусственной слезы наиболее важным для лечения ССГ параметром.

Ключевые слова: глаукома; заболевания; ассоциированные с сухим глазом; синдром сухого глаза; препараты искусственной слезы

Конфликт интересов: отсутствует.

Прозрачность финансовой деятельности: проведение анкетирования и его анализ поддержан Аджанта Фарма, Лтд. Для цитирования: Маскати К.Б., Кумар Ш., Чоби В., Катаквар Н., Шарма С. Синдром сухого глаза и связанные с ним факторы в Казахстане и Узбекистане. Российский офтальмологический журнал. 2021; 14 (2): 63-8. https://doi. org/10.21516/2072-0076-2021-14-2-63-68

Dry eye (DE) is a commonly occurring disease of the ocular surface and affects millions of individuals globally. The 2017 report of the Tear Film and Ocular Surface Society International Dry Eye Workshop II gives the definition of DE disease (DED) as "a multifactorial disease of the ocular surface characterised by a loss of homeostasis of the tear film, and accompanied by ocular symptoms, in which tear-film instability and hyperosmolarity, ocular surface inflammation and damage, and neurosensory abnormalities play etiological roles" [1]. It is characterised by degradation of the tear film and inflammation of the lacrimal glands and ocular surface $[2,3]$.

The global prevalence of DED ranges from 5\% to $34 \%$ [4]. The incidence doubles in those aged 59 years and above and about one out of seven individuals aged 65 to 84 years are affected. There is a progressive increase in the incidence of DED with increase in pollution and lifestyle changes such as the use of computers and air-conditioners [2].

DED is clinically classified into two subtypes: 1) aqueous deficient (tear deficiency); 2) hyper evaporative (increased evaporation).

Mixed forms of the condition are common [4]. The symptoms range from slight discomfort to disabling pain and fluctuating vision [1]. Most symptoms of DED such as redness, stinging, pruritus, photophobia and foreign body sensation are subjective and nonspecific [4]. The symptoms make it difficult to read and use a computer for extended periods, thus affecting workplace productivity. The symptoms also influence regular activities such as reading, driving and other recreational activities, which results in an overall decrease in quality of life [1].

Causes of DED include dysfunction of the meibomian or lacrimal glands, environmental factors (e.g., allergens, dry climate and cigarette smoke), systemic disorders (e.g., diabetes mellitus, rheumatoid arthritis and thyroid diseases), hormonal imbalance (e.g., perimenopausal women and patients undergoing hormone replacement therapy), neurotrophic deficiency, use of contact lens, Sjögren syndrome, previous eye surgery (e.g., refractive surgery and corneal transplantation), computer vision syndrome (caused by decreased blinking while using a computer screen) and long-term use of systemic medications such as antidepressants, antihistamines, cholesterol-lowering agents, beta-blockers and oral contraceptives $[3,5,6]$.

Due to decreased hormonal levels that result in decreased secretions from the lacrimal glands and loss of anti-inflammatory protection, postmenopausal women are at a greater risk of DE. Reduction in hormonal levels leads to a decrease in secretions of the lacrimal gland and loss of anti-inflammatory protection [3, 7]. Prevalence of DED increases with ageing in general population [4].

DED is challenging to diagnose as it is multifactorial [8]. The foremost aim in the treatment of DEs is to relieve symptoms and to reduce the risk of ocular surface damage [9]. The first line of treatment usually involves the administration of artificial tears, followed by anti-inflammatory agents, tetracyclines, punctal plugs, secretagogues, systemic immunosuppressives and surgical intervention [5, 9].

This survey was conducted to assess the perspective and understanding of the doctors regarding the prevalence of DED in the population of Kazakhstan and Uzbekistan, ocular diseases associated with DED, the use of artificial tears, poor adherence to DE treatment, major concerns about DE therapy, essential properties in artificial tears and the use of artificial tears in other ocular diseases.

\section{MATERIAL AND METHODS}

This study uses the questionnaire based on a survey prepared for 2017 report of the Tear Film and Ocular Surface Society International Dry Eye Workshop II article. The countries chosen for the survey were Kazakhstan and Uzbekistan, and the study was conducted between June-July 2019. The questionnaire included nine questions, in both English and Russian languages, for the convenience of the doctors. Each doctor was asked to fill in their full name, the name of their clinic and the date of the survey. Types of questions in the survey were: a) multiple-choice questions, b) fill in the blank, c) both, d) rate the option on a scale of 1-4 or 1-5.

The cities covered in Kazakhstan for the survey were Almaty, Astana, Karaganda, Pavlodar, Shymkent, Taldykorgen and Taraz, while the cities covered in Uzbekistan were Tashkent, Samarkand, Bukhara, Namangan, Andijan, Fergana, Kakand and Navoi. Medical representatives (MRs) visited the ophthalmologists who were willing to participate in the survey in their respective cities. The purpose of the survey was explained to the doctors, and those willing to participate were enrolled in the survey. A total of 457 ophthalmologists participated in the survey, of which 248 were from Kazakhstan and 209 were from Uzbekistan. The MRs were trained to provide any explanation regarding the questionnaire if needed. Each survey form was filled manually by the ophthalmologists and collected by the respective MR. The filled questionnaires were analysed using SPSS software version 23 .

Chi-square analysis was used to find the association between patients' adherence to DED therapy and factors such as associated ocular diseases and the patient's lifestyle, major concerns 
of DED, the properties of artificial tears that doctors look for in the treatment of DED and whether glaucoma is a significant concern for DED.

\section{RESULTS}

A statistical analysis of the questionnaire survey received from the doctors found that a majority of the doctors in the study sample $(69.7 \%)$ diagnosed DED based on the signs and symptoms of a patient. Among the doctors from Kazakhstan, 74.7 \%, $6.8 \%$ and $18.5 \%$ looked at the signs and symptoms, existing diseases and the patient's lifestyle, respectively, for the diagnosis of DED. Of the doctors from Uzbekistan, $65.4 \%, 24.7 \%$ and $9.9 \%$ looked at the signs and symptoms, existing diseases and the patient's lifestyle, respectively.

A majority of the doctors in the study sample (47.48\%) reported seeing 5-10 patients with DE/day. In Kazakhstan, the number of patients with $\mathrm{DE} /$ day was reported as follows: $38.71 \%$ of the doctors reported $<5$, a majority of them $(55.24 \%)$ reported $5-10$, and $6.05 \%$ reported $10-20$. In Uzbekistan, the number of patients with $\mathrm{DE} /$ day was reported as follows: a majority of the doctors $(51.67 \%)$ reported $<5,38.28 \%$ reported $5-10,7.18 \%$ reported $10-20$, and $0.96 \%$ reported $>20$; about $1.91 \%$ did not answer the question.

Data was analysed to determine in which cities the doctors reported seeing more DED patients/day. In Kazakhstan, doctors in Astana, Pavlodar, Shymkent and Karaganda reported seeing a higher number of patients with DE than in other cities. In Uzbekistan, compared to other cities, doctors in Fergana, Kakand and a few parts of Tashkent (Tashkent-3, Tashkent-4, Tashkent-5 and Tashkent-9) reported seeing a higher number of patients with DE.

A majority of doctors in the study population (19\%) mentioned glaucoma as a common eye disorder associated with DE (Figure 1). Apart from glaucoma, $12 \%$ and $9 \%$ of total doctors also reported conjunctivitis and myopia respectively as common eye disorders associated with DE. In Kazakhstan, a majority of doctors reported glaucoma (38\%) and conjunctivitis $(28 \%)$ as eye disorders associated with DE. In Uzbekistan, a majority of doctors reported glaucoma (30\%) and myopia (20\%) as eye disorders associated with DE. A majority of the doctors $(55.14 \%)$ in the study sample reported $20-50 \%$ of glaucoma patients suffering from DE (Figure 2).

In Kazakhstan, $66.9 \%$ of the doctors reported that 20-50\% of glaucoma patients had DE, whereas, in Uzbekistan, $41.1 \%$ of the doctors reported the same. About $14.1 \%$ of the doctors in Kazakhstan reported that less than $20 \%$ of the glaucoma patients had DE, whereas $39.2 \%$ of the doctors in Uzbekistan reported the same. Ten doctors in Uzbekistan chose not to comment on the prevalence of DE in glaucoma patients.

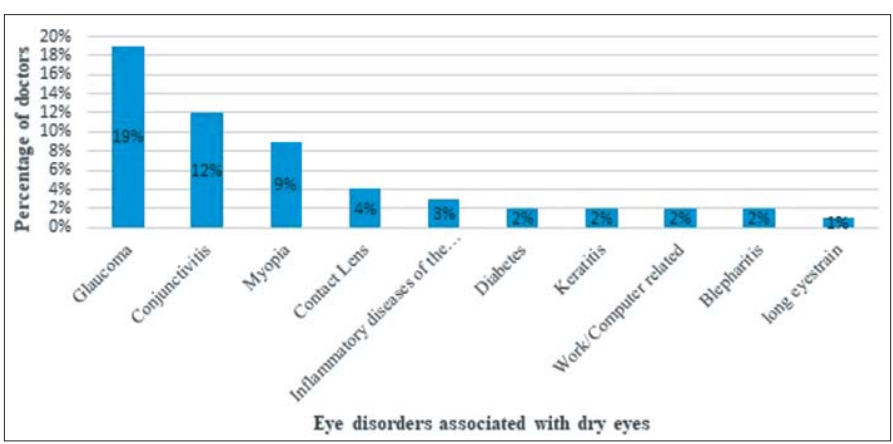

Fig. 1. Eye disorders associated with dry eyes reported by the doctors in the study sample

Рис. 1. Глазные заболевания, ассоциированные с синдромом сухого глаза, в выборке исследования
Chi-square analysis was conducted to see if there is an association between the number of patients with DE and the percentage of glaucoma patients with DE seen by the doctors per day. This analysis was done to understand whether glaucoma is a significant concern for DE. The Pearson chi-square test was found to be statistically significant, with a P-value of 0.006 (P-value significant at $<0.05)$. A majority of the doctors $(83.59 \%)$ in the study sample reported that adherence to therapy is a major challenge in the treatment of DE (Figure 3). About $15.54 \%$ of the total doctors reported that adherence to therapy is not a concern in DE, and four doctors from Uzbekistan chose not to comment.

A majority of doctors in the total study sample $(85.34 \%)$ reported that both DE associated eye disease and patient lifestyle are responsible for poor patient adherence to DE therapy. $14.22 \%$ of the doctors in the total study sample reported that poor adherence is solely the result of patient lifestyle. A majority of doctors in Kazakhstan (73\%) and all the doctors in Uzbekistan reported that poor adherence to DE therapy is associated with ocular disease and patient lifestyle. In Kazakhstan, $26.2 \%$ of doctors reported that patient lifestyle is solely responsible for poor patient adherence in DE therapy.

Chi-square analysis was performed to find the association between adherence to DED therapy and factors such as ocular diseases and the patient's lifestyle in patients in Kazakhstan. The Pearson chi-square test was found to be statistically significant, with a $\mathrm{P}$-value of 0.000 ( $\mathrm{P}$-value significant at $<0.05)$.

Unsurprisingly, a majority of the doctors $(52.74 \%)$ in the study sample reported tear film instability as their most important concern in DE (Figure 4).

Among the properties required to be considered in any artificial tear drops (such as hydrating, mucoadhesive, having the ability to repair deoxyribose nucleic acid (DNA) damage in cells of ocular surface, anti-inflammation, antioxidant), a majority of doctors $(63.68 \%)$ in the study sample reported 'hydrating' as the property of highest concern required in any artificial tear drops (Figure 5).

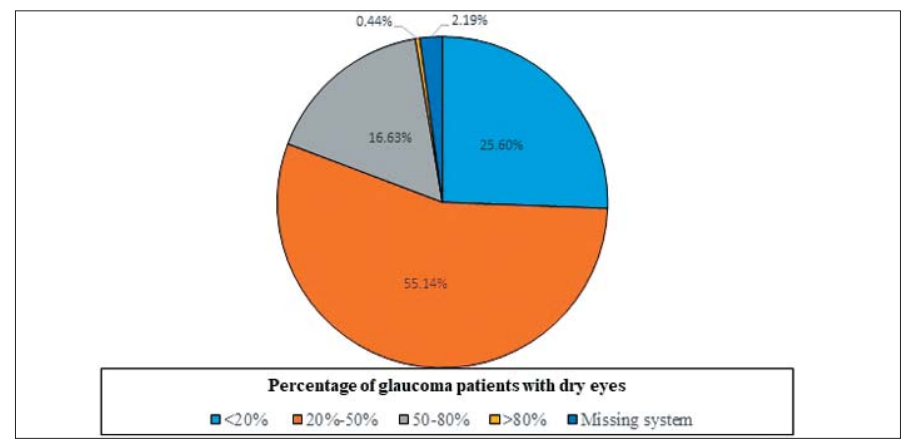

Fig. 2. Percentage of doctors in the study sample and the percentage of their glaucoma patients with dry eyes

Рис. 2. Доля докторов в выборке исследования, указавших соответствующий процент их пациентов с глаукомой, имеющих ССГ

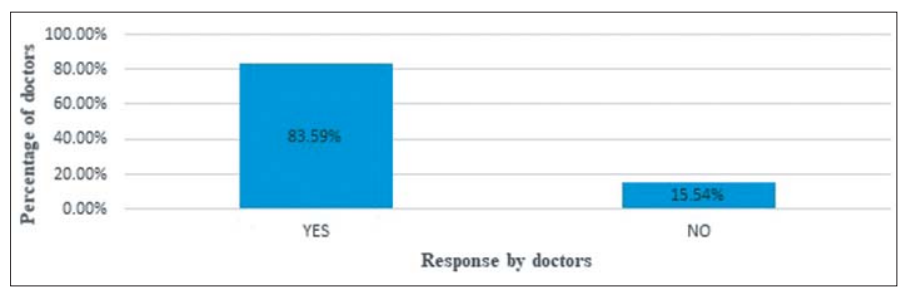

Fig. 3. Percentage of doctors in the study sample who felt that adherence to therapy is a major challenge in the treatment of dry eyes

Рис. 3. Доля докторов в выборке исследования, указавших, что приверженность к лечению - главный фактор в лечении ССГ 


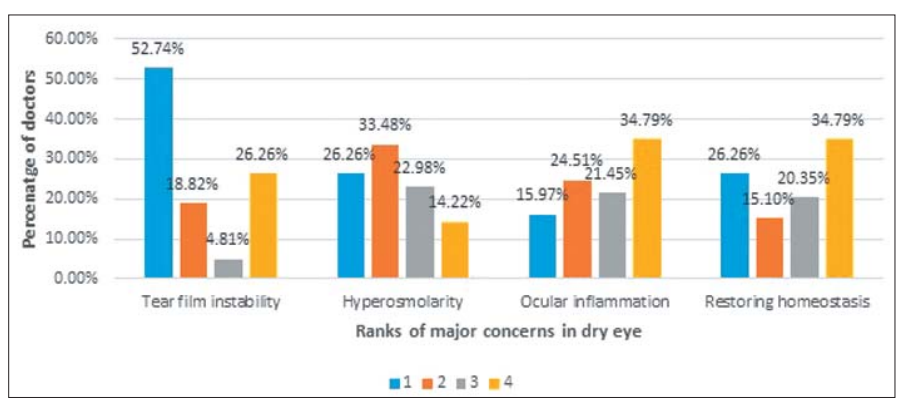

Fig. 4. Ranks of major concerns in dry eyes (Total population) (1 being highest priority \& 4 being lowest priority)

Рис. 4. Ранжирование основных причин, вызывающих ССГ (в популяции в целом) (1 балл - наиболее важная причина, 4- наименее важная причина)

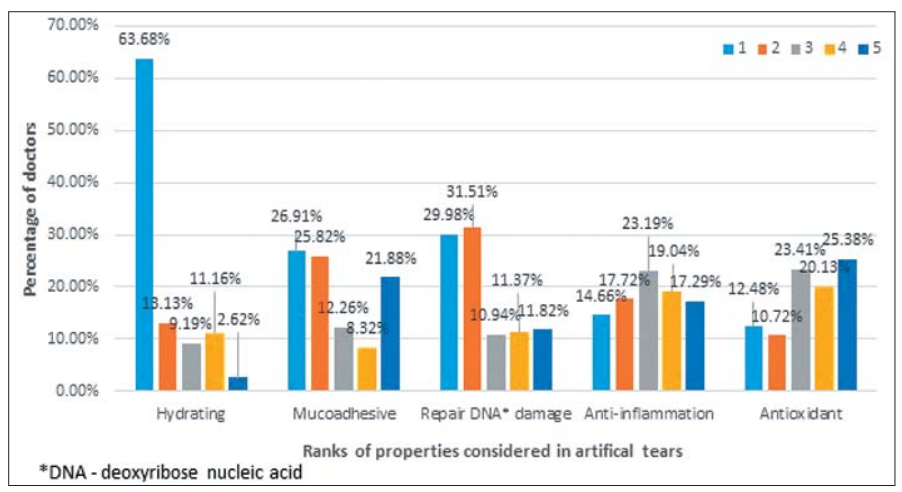

Fig. 5. Ranks of properties considered in artificial tear drops (Total population) ( 1 being highest priority $\& 5$ being lowest priority)

Рис. 5. Ранжирование характеристик препаратов искусственной слезы (в популяции в целом) (1 балл - наиболее важное свойство, 5 - наименее важное свойство)

A correlation analysis was performed between the major concerns in DE and properties being looked for while considering artificial tears. Doctors who are likely to rate ocular inflammation as a major concern considered anti-inflammatory as a significant $(\mathrm{P}$ value $<0.05)$ property in artificial tears. Similarly, doctors who rated tear film instability as a primary concern considered mucoadhesion a significant $(\mathrm{P}$ value $<0.05)$ property in artificial tears. Doctors who rated hyperosmolarity as a major concern considered mucoadhesion and DNA repair as significant $(\mathrm{P}$ value $<0.05$ ). Doctors who rated restoring homeostasis as a major concern considered antioxidant, anti-inflammatory, hydrating and DNArepairing properties significant $(\mathrm{P}$ value $<0.05)$ in artificial tears.

Doctors from Kazakhstan and Uzbekistan reported the use of artificial tears in many conditions other than DED. A majority of the doctors in the study sample reported that artificial tears can be prescribed for glaucoma (19\%) and conjunctivitis (19\%). Doctors in Kazakhstan reported the use of artificial tears in conditions such as glaucoma (11\%), conjunctivitis ( $28 \%$ ), after intervention (22\%) and with the use of contact lens (15\%). In Uzbekistan, the most commonly reported conditions that prompted the use of artificial tears were glaucoma ( $22 \%)$, the use of contact lens (13\%) and keratitis (17\%). Other conditions that warranted artificial tear use as per doctors from both countries were blepharitis, diabetes, after work/computer/electronic device use, arthritis, uveitis, allergy, climate, cataract, eye injury and myopia.

\section{DISCUSSION}

Our study aimed to understand the association between various eye disorders and dry eye disease, and their treatments, as observed by ophthalmologists in their everyday practice. A majo- rity of the doctors in the study reported adherence to therapy as a significant challenge in the treatment of DE. All the doctors in Uzbekistan and a majority of the doctors in Kazakhstan attributed poor adherence to DE treatment to associated ocular diseases and the patient's lifestyle. This association was found to be statistically significant $(\mathrm{P}$-value $<0.05)$.

Ocular conditions most frequently seen to be associated with DEs are glaucoma, conjunctivitis and myopia. Globally, $40-50 \%$ of glaucoma patients are seen to have DEs. A majority of the doctors in Kazakhstan and Uzbekistan reported that 20-50\% of glaucoma patients had DEs. Chi-square analysis of the number of patients/day and the percentage of glaucoma patients with DED in both Kazakhstan and Uzbekistan showed that glaucoma has a strong association with DED (P-value $<0.05)$. The treatment of DED, although challenging for both the doctor and the patient, is important for the comfort and long-term health of the surface of the patient's eye [10].

Apart from glaucoma, allergic conjunctivitis (AC) and DED are two of the most common anterior inflammatory disorders of the ocular surface that have some similar symptoms. A study conducted by M. Hom et al., found that pre-existing AC predisposes an individual to DED [11].

According to a study conducted by N. Ilhan, et al., patients with pathological myopia have lower tear breakup time (TBUT) scores, a sign of tear film instability, and high ocular surface disease index (OSDI) scores as compared to healthy individuals. This supports the relationship between pathological myopia and tantalic DED as many patients with high myopia had severe symptoms (based on OSDI scores), which was indicative of ocular surface irritation [12].

Lifestyle factors contributing to DE are long periods of eyestrain caused by computer use at work and using contact lens. Studies show a significant decrease in tear volume after computer use. After a routine day at work, computer users showed a reduced Schirmer score and reduction in tear breakup time. A study by S. Jaiswal et al., found that regular computer users had higher expression of pro-inflammatory mediators. Computer use of longer than four hours/day led to adverse changes in the quality of meibum expression and longer than seven hours/day showed higher levels of tear osmolarity, a diagnostic marker of DEs [13]. These point to a greater need for artificial tears in individuals using computers for extended periods of time.

Contact lens discomfort (CLD) is another common lifestyle contributor to DEs necessitating the use of artificial tears. The number of contact lens wearers worldwide has remained constant over the past decade despite the advances in technology as $10-50 \%$ of them stop using them within three years, with CLD being cited as the most common cause. About $70 \%$ of individuals report CLD late in the day after wearing contact lens, with $40 \%$ of the soft contact lens wearers reporting a sensation of DE. CLD is caused by incompatibility between the contact lens and the ocular environment and results in ocular changes such as conjunctival indentation or staining, formation of conjunctival epithelial flap, Demodex blepharitis, lid wiper epitheliopathy, and meibomian gland dysfunction. Reduced goblet cell density and conjunctival metaplasia are linked to CLD, leading to an effect on the TBUT of contact lens users. These factors show a strong link between CLD and friction [14].

Tear film instability, hyperosmolarity and ocular inflammation play an etiological role in the loss of homeostasis of the ocular surface, resulting in DED [8]. As artificial tears are used as the first-line of treatment in DED [9], doctors participating in this study looked for properties in artificial tears that could target these conditions to restore homeostasis of the ocular surface. 
Tear film instability. Some factors affecting tear film instability are ocular surface inflammation, delay in tear clearance, reduction in the quantity and quality of the lipid layer, compromised tear components, irregularities in the ocular surface and reduced tear production. A decrease in the lipid layer of the ocular surface results in evaporation of the aqueous layer and slows down lipid transport. Eventually, dehydration results in the glycocalyx layer losing its hydrophilic property and rupture of the tear film [5].

According to our survey, doctors who cited tear film instability as a primary concern in patients with DE looked for mucoadhesive properties in artificial tears. Water-soluble polymers such as carboxymethylcellulose, hyaluronic acid, polyethylene glycol, hypromellose, hydroxyethylcellulose, methylcellulose, glycerine, propylene glycol, polysorbate and polyacrylic acid are used in artificial tears for their mucoadhesive property. These polymers have hydroxyl or carboxyl groups that interact by forming hydrogen bonds with water molecules on the ocular surface and assist in mucoadhesion of artificial tears on the ocular surface. The polymers also increase the viscosity of artificial tears and their retention time. Lipid-containing artificial tears are used to compensate for the deficient lipid layer. These lipids help to prevent the tear film from evaporation. The active ingredients in such formulations include mineral oil, glycerine, castor oil and polypropylene glycol at varying concentrations [5].

Tear film hyperosmolarity. Hyperosmolarity is considered to play an essential role in the pathogenesis of DEs. The tear film osmolarity test is regarded as 'gold standard' in the diagnosis of DE [15]. Lacrimal gland dysfunction and an increase in evaporation of the aqueous tear phase lead to an increase in tear film osmolarity $[5,16]$. According to a study conducted by R. Deng, et al., increased production of reactive oxygen species (ROS) was observed in human cell epithelium corneal cells (HCECs) when exposed to media with high osmolarity. Excess production of ROS damages lipids and other macromolecules and results in oxidative stress. Oxidative stress of mitochondria is associated with many pathological processes that influence apoptosis. Aconitase-2, a multifunctional enzyme, plays a role in oxidative phosphorylation. The enzyme count increases with increased mitochondrial metabolism under oxidative stress. Oxidative DNA damage following ROS-induced specific enzymatic cleavage by ROS-induced 8-hydroxylation of the guanine base in nuclear and mitochondrial DNA produces 8-hydroxy-2'-deoxyguanosine (8-OHdG). Human cell epithelium corneal cells exposed to media with increased osmolarity show increased production of aconitase- 2 and $8-\mathrm{OHdG}$ due to mitochondrial DNA damage that occurs in HCECs under hyperosmolarity conditions [16]. Our survey also shows that doctors who rate hyperosmolarity as a vital factor in DED looked for properties in artificial tears that could repair the damaged DNA. $\mathrm{N}$-acetylcarnosine is a prodrug of mitochondria L-carnosine. When combined with other antioxidants, it can prevent oxidation of the tissue and cellular structures of the ocular compartments effectively. $\mathrm{N}$-acetylcarnosine used with synergistic lubricants provides therapeutic results in DED [17].

Ocular inflammation. Hyperosmolarity triggers inflammation [18]. Environmental stress to the ocular surface sensitizes the conjunctival and corneal antigen-presenting cells, which results in the production of $\mathrm{T}$-helper cells that release inflammatory cytokines. These cytokines amplify immune response and lead to the damage of ocular surface epithelial cells. Studies suggest that excessive environmental stress to ocular surface or immunoregulatory dysfunction coupled with genetic factors or hormonal imbalance provides an environment favorable for the activation of autoreactive T and B lymphocytes. These lymphocytes form the foundation of autoimmune-mediated pathology such as DED [5]. This explains why doctors who rate ocular inflammation as the central concern in DED considered anti-inflammatory property to be essential in artificial tears [19].

Restoring homeostasis. The loss of homeostasis of the tear film is one of the primary characteristics of DE. A vicious cycle of inflammation is considered a key factor in DE and comprises tear film instability, tear hyperosmolarity, apoptosis of conjunctival/ corneal cells, and inflammation in the ocular surface. Various factors, both intrinsic and extrinsic, accelerate the cycle and aggravate DED by causing stress to the ocular surface [20]. A cross-analysis of data from our survey shows that doctors who considered restoring ocular homeostasis as a major concern looked for properties in artificial tears such as hydrating the ocular surface; repairing damaged DNA; and having anti-inflammatory agents and antioxidants that could deal with tear film instability, hyperosmolarity and ocular inflammation, and apoptosis of ocular cells.

A broad range of treatment methods is available for DED. Some components of the treatments should be checked as they could interfere with the function of other components of the ocular surface and increase complications or exacerbate DED [5]. Benzalkonium chloride (BAK) has been one of the most used preservatives in ophthalmic preparations. However, long-term use of BAK is exceptionally toxic to the ocular surface. Oxidative preservatives such as sodium perborate and stabilised oxychlorocomplex (SOC) are better alternatives due to low toxicity and less corneal damage, respectively. Sodium perborate is converted to hydrogen peroxide when combined with water and when in contact with the ocular surface, it decomposes to oxygen and water. However, some studies mention that hydrogen peroxide causes a stinging sensation even at low concentrations. SOC composed of chlorate, chlorite and trace amounts of chlorine dioxide has anti-viral and anti-bacterial properties. It releases chlorine dioxide-free radicals that have antimicrobial activity when in solution and gets converted into oxygen, water, and sodium and chloride ions on administration to the ocular surface. On using medication preserved with SOC, less corneal damage and significantly lower number of inflammatory cells in corneal epithelium were observed as compared to medications with BAK in an in vivo study using a rabbit model [21].

\section{CONCLUSION}

DE is a commonly occurring condition of the ocular surface and can affect the quality of life. A patient's lifestyle habits such as long-term computer use and the use of contact lens are a major concern in adherence to DED therapy. Artificial tears are the first line of treatment in DED, and it is essential that they hydrate the ocular surface adequately. Larger studies in patients can help identify ways to improve adherence to therapy and improve quality of life in patients.

\section{References/Jumepamypa}

1. Clayton J.A. Dry eye. N. Engl. J. Med. 2018; 378 (23): 2212-23. doi: 10.1056/ NEJMra 1407936

2. Singh A.K. Review of various lacrimomimetics: making the appropriate choice. Delhi J. Ophthal. 2019; 29 (3): 13-8. doi: 10.7869/djo.410

3. Javadi M.A., Feizi S. Dry eye syndrome. J. Ophthalmic. Vis. Res. 2011; 6(3): 192-8. https://www.ncbi.nlm.nih.gov/pmc/articles/PMC3306104/

4. Messmer E.M. The pathophysiology, diagnosis, and treatment of dry eye disease. Dtsch. Arztebl. Int. 2015; 112 (5): 71-81. doi: 10.3238/arztebl.2015.0071

5. Zhang X., M V.J., Qu Y, et al. Dry eye management: targeting the ocular surface microenvironment. Int. J. Mol. Sci. 2017; 18 (7): 1398. doi: 10.3390/ ijms 18071398

6. Golden M.I., Meyer J.J., Patel B.C. Dry eye syndrome. Treasure Island, FL: StatPearls Publishing; 2019. Available at: https://www.ncbi.nlm.nih.gov/books/ NBK470411/

7. Peck T., Olsakovsky L., Aggarwal S. Dry eye syndrome in menopause and perimenopausal age group. J. Midlife Health. 2017; 8 (2): 51-4. doi: 10.4103/ jmh.JMH $41 \_17$

8. Karmel M. A quick guide to dry eye. Available at: https://www.aao.org/eyenet/ article/quick-guide-to-dry-eye? 
9. Findlay $Q$., Reid $K$. Dry eye disease: when to treat and when to refer. Aust. Prescr. 2018; 41 (5): 160-3. doi: 10.18773/austprescr.2018.048

10. Williams R.D. Dry eyes and glaucoma: double trouble. Glaucoma Research Foundation. Available at: https://www.glaucoma.org/treatment/dry-eyesand-glaucoma-double-trouble.php

11. Hom M.M., Nguyen A.L., Bielory L. Allergic conjunctivitis and dry eye syndrome. Ann. Allergy Asthma Immunol. 2012; 108 (3): 163-6. doi: 10.1016/j.anai.2012.01.006

12. Ilhan N., Ilhan O., Tuzcu E.A., et al. Is there a relationship between pathologic myopia and dry eye syndrome? Cornea. 2014; 33 (2): 169-71. doi: 10.1097/ ICO.0000000000000033

13. Jaiswal S., Asper L., Long J., et al. Ocular and visual discomfort associated with smartphones, tablets and computers: what we do and do not know. Clin. Exp. Optom. 2019; 102 (5): 463-7. doi: 10.1111/cxo.12851

14. Markoulli M., Kolanu S. Contact lens wear and dry eyes: challenges and solutions. Clin. Optom. (Auckl). 2017; 9: 41-8. doi: 10.2147/OPTO.S111130

15. Hirata H., Mizerska K., Dallacasagrande V., Rosenblatt M.I. Estimating the osmolarities of tears during evaporation through the «eyes» of the corneal nerves. Invest. Ophthalmol. Vis. Sci. 2017; 58 (1): 168-78. doi: doi.org/10.1167/iovs.16-20501
16. Deng R., Hua X., Li J., et al. Oxidative stress markers induced by hyperosmolarity in primary human corneal epithelial cells. PLoS One. 2015; 10 (5): e0126561. doi: 10.1371/journal.pone.0126561

17. Babizhayev M.A. Generation of reactive oxygen species in the anterior eye segment. Synergistic codrugs of $\mathrm{N}$-acetylcarnosine lubricant eye drops and mitochondria-targeted antioxidant act as a powerful therapeutic platform for the treatment of cataracts and primary open-angle glaucoma. BBA Clin. 2016; 6: 49-68. doi: 10.1016/j.bbacli.2016.04.004

18. Lollett I.V., Galor A. Dry eye syndrome: developments and lifitegrast in perspective. Clin. Ophthalmol. 2018; 12: 125-39. doi: doi.org/10.2147/OPTH. S126668

19. Pucker A.D., Ng S.M., Nichols J.J. Over the counter (OTC) artificial tear drops for dry eye syndrome. Cochrane Database Syst Rev. 2016; 2: CD009729. doi: 10.1002/14651858.CD009729.pub2

20. Yamaguchi T. Inflammatory response in dry eye. Invest. Ophthalmol. Vis. Sci. 2018; 59(14): 192-9. doi: 10.1167/iovs.17-23651

21. Walsh K., Jones $L$. The use of preservatives in dry eye drops. Clin. Ophthalmol. 2019; 13: 1409-25. doi: 10.2147/OPTH.S211611

Author contributions: Qureshi Maskati, Shalini Kumar - significant participation in the development of the concept and design of the study, in the collection of data and in their interpretation, preparation (writing) of an article or significant processing of its substantive part; Vijaykumar Chaubey, Neelesh Katakwar, Siddhesh Sharma - final preparation of the draft article for publication.

Вклад авторов в работу: К.Б. Маскати, Ш. Кумар - значимое участие в разработке концепции и дизайна исследования, в сборе данных и их интерпретации, подготовка (написание) статьи или значимая подготовка ее существенной части; В. Чоби, Н. Катаквар, С. Шарма финальная подготовка статьи к публикации.

Originally received: 01.12.2020. Final revision: 16.12.2020. Accepted: 20.12.2020

Поступила: 01.12.2020. Переработана: 16.12.2020. Принята к печати: 20.12.2020

\section{INFORMATION ABOUT THE AUTHORS/ ИНФОРМАЦИЯ ОБ АВТOРАХ}

Maskati Eye Clinic, Maharshi Karve Road, Charni Road East, Opera House, Girgaon, Mumbai, 400004, India

Quresh B. Maskati - MS, DOMS, FCPS, FICS, ophthalmologist Ajanta Pharma Limited, Unit No. 301/302, Satellite Gazebo, B Wing, Andheri Ghatkopar Link Road, Chakala, Andheri East, Mumbai, 400093, India Shalini Kumar - MBBS, MD, Head Medical Services, Global Medical and Clinical Research

Vijaykumar Chaubey - B. Pharma, MBA, Product Manager, Ophthalmology, Global Marketing and Strategy Research

Neelesh Katakwar - B. Pharma, MBA, Marketing Manager, Ophthalmology, Global Marketing and Strategy Research

Siddhesh Sharma - B. Pharma, M. Pharma, Global Medical and Clinical Research

Contact information: Dr. Quresh Maskati, rachita@spellbound.co.in
Глазная клиника Маскати, Махарши Карве Роуд, Чарни Ист Роуд, Здание Оперы, Жиргаон, Мумбаи, 400004, Индия

Куреш Б. Маскати - MS, DOMS, FCPS, FICS, офтальмолог

Аджанта Фарма Лтд, блок 301/302, Сателлайт Газибо, Винг Б, Андери Гаткопар Линк Роуд, Чакала, Восточное Андери, Мумбаи, 400093, Индия

Шалини Кумар - MBBS, MD, глава медицинской службы, общие медицинские и клинические исследования

Виджайкумар Чоби - бакалавр по фармакологии, МВА, продакт-менеджер, офтальмология, общий маркетинг и стратегия исследований Неелеш Катаквар - бакалавр по фармакологии, МВА, менеджер по маркетингу, офтальмология, общий маркетинг и стратегия исследований

Сиддхеш Шарма - бакалавр и магистр, общемедицинские и клинические исследования

Для контактов: Куреш Б. Маскати, rachita@spellbound.co.in 